\title{
PENGARUH KARAKTERISTIK INDIVIDU TERHADAP KINERJA AUDITOR (Studi Empiris pada Kantor Akuntan Publik di Jakarta Selatan)
}

\author{
Galih Chandra Kirana, SE.,M.Ak \\ dan \\ Eva Shalehah \\ Fakultas Ekonomi Jurusan Akuntansi \\ Universitas Satya Negara Indonesia
}

\begin{abstract}
This study aims to determine the effect of individual characteristics on the performance of auditors, empirical studies at public accounting firm in South Jakarta. Individual characteristics of the auditor's performance can increase knowledge about the need to maintain and improve locus of control and organizational commitment to auditor performance in KAP to improve its quality in work

Population in this research is auditor working in Public Accountant Office of South Jakarta registered in IAPI either partially or simultaneously. The sample used in this study as many as 100 respondents from 12 Public Accounting Firm. The data of this research are primary data obtained through questionnaires distribution. The sampling technique used purposive sampling method, while the data processing method used by the researcher is multiple linear analysis with the help of SPSS version 21.0.

The results of this study indicate that the locus of contol and organizational commitment partially have a positive and significant influence, and the influence of locus of contol and organizational commitment simultaneously have a positive and significant effect on auditor's performance of $61 \%$, while $39 \%$ is explained by other variables not included in this research model.
\end{abstract}

Keywords: locus of contol, organizational commitment, auditor performance

\begin{abstract}
ABSTRAK
Penelitian ini bertujuan untuk mengetahui pengaruh karakteristik individu terhadap kinerja auditor, studi empiris pada kantor akuntan publik di Jakarta Selatan. Karakteristik individu terhadap kinerja auditor dapat menambah pengetahuan tentang perlunya menjaga dan meningkatkan locus of control dan komitmen organisasi terhadap kinerja auditor di KAP untuk meningkatkan kualitasnya dalam bekerja

Populasi dalam penelitian ini adalah auditor yang bekerja di Kantor Akuntan Publik Jakarta Selatan yang terdaftar di IAPI baik secara parsial maupun secara simultan. Sampel yang digunakan pada penelitian ini sebanyak 100 responden dari 12 Kantor Akuntan Publik. Data penelitian ini adalah data primer yang diperoleh melalui penyebaran kuesioner. Teknik pengambilan sampel menggunakan metode purposive sampling, sedangkan metode
\end{abstract}


pengolahan data yang digunakan peneliti adalah analisis linear berganda dengan bantuan SPSS versi 21.0.

Hasil penelitian ini menunjukkan bahwa locus of contol dan komitmen organisasi secara parsial berpengaruh positif dan signifikan, Dan pengaruh locus of contol dan komitmen organisasi secara simultan berpengaruh positif dan signifikan terhadap kinerja auditor sebesar 61\% Sedangkan sebagiannya sebesar 39\% dijelaskan oleh variabel lain yang tidak termasuk dalam model penelitian ini.

Kata Kunci: locus of contol, komitmen organisasi, kinerja auditor

\section{PENDAHULUAN}

Persaingan dunia usaha akan semakin meningkat dalam menghadapi ASEAN Economic Community (AEC). AEC ini akan memiliki dampak positif dan negatif bagi perkembangan kantor akuntan publik. Pembentukan komunitas ekonomi tersebut akan memberikan implikasi terciptanya pasar tunggal dan dapat memicu persaingan bisnis di wilayah Asia Tenggara. ASEAN Economic Community memberikan peluang dan keuntungan bagi dunia bisnis, karena terjadi peningkatan akses pasar antar negara-negara ASEAN. Perusahaanperusahaan dapat memperluas cakupan pangsa pasar, aliran investasi, modal dan tenaga kerja yang terampil. Namun demikian kondisi tersebut juga memiliki konsekuensi bagi dunia bisnis. Hal ini terjadi karena dengan terbukanya akses dari kawasan ASEAN tentunya terjadi peningkatan tuntutan pengguna laporan keuangan terhadap disajikannya laporan keuangan yang berintegritas tinggi (Ceacilia Sri Mindarti, 2015)

Auditor memiliki peran yang sangat penting dalam memberikan jaminan atas kewajaran laporan keuangan. Jaminan tersebut dinyatakan dalam opini yang menyatakan kewajaran laporan keuangan klien. Opini auditor atas laporan keuanganakan digunakan sebagai acuan oleh para pengguna laporan keuangan dalam mengambil keputusan. Opini yang tidak sesuai dengan kondisi klien akan dianggap sebagai informasi yang menyesatkan. Untuk dapat menghasilkan opini yang terpercaya Auditor harus memiliki bukti kompeten yang memadai dan melaksanakan seluruh tahapan audit dengan seksama.

Dalam melaksanakan tugasnya, auditor harus mengikuti standar audit. Standar tersebut terdiri dari standar umum, standar pekerjaan lapangan, standar pelaporan serta kode etik akuntan. Standar auditing merupakan pedoman bagi auditor dalam menjalankan tanggung jawab profesionalnya. Standar tersebut harus dipatuhi oleh Akuntan Publik yang beroperasi sebagai A Menurut Fanani et.al (2008) dalam Desak Made Putri Sanjiwanti dan I Gede Suparta Wisadga (2016). Kinerja auditor merupakan hasil kerja yang dicapai oleh auditor dalam melaksanakan tugasnya sesuai dengan tanggung jawab yang diberikan padanya. Dan menjadi salah satu tolak ukur yang digunakan untuk menentukan apakah suatu pekerjaan yang dilakukan akan baik atau sebaliknya. Kinerja auditor menjadi perhatiaan utama, baik bagi klien ataupun publik. Dalam menilai hasil audit yang dilakukan. Kinerja auditor dipengaruhi oleh beberapa faktor beberapa diantaranya adalah adanya konflik peran dalam lingkungan organisasi, adanya ketidak jelasan peran yang dialami auditor serta komitmen organisasi dari setiap auditor dalam melaksankan tugas audit.

Faktor-faktor yang memengaruhi kinerja auditor dapat berupa faktor individu dan lingkungan (Bonner dan Sprinkle 2002). Penelitian ini lebih difokuskan kepada faktor karakteristik individu. Hal ini didasarkan pada teori atribusi yang menyatakan bahwa "sumber perilaku individu bisa dari faktor internal (karakteristik individu) dan faktor 
eksternal (lingkungan)". uditor Independen (Arens dan Loebbecke, 2013 dalam Ceacilia Sri Mindarti, 2015)

Menyebutkan bahwa peningkatan kinerja dalam pekerjaannya dipengaruhi oleh kondisi-kondisi tertentu, yaitu kondisi yang berasal dari dalam individu yang disebut faktor individual dan kondisi yang berasal dari luar individu yang disebut dengan faktor situasional. Faktor individual meliputi jenis kelamin, kesehatan, pengalaman dan karakteristik psikologis yang terdiri dari locus of control dan Komitmen Organisasi.

\section{Locus Of Control}

\section{LANDASAN TEORI}

Locus of control merupakan suatu konsep yang dikembangkan oleh Rotter pada tahun 1966. Rotter menyatakan bahwa individu-individu mengembangkan ekspektasi-ekspektasi mengenai kesuksesan mereka dalam situasi terentu akan tergantung pada perilaku personal mereka atau dikendalikan oleh pihak diluar dirinya.

Locus of control adalah persepsi tentang kendali mereka atas nasib, kepercayaan diri dan kepercayaan mereka atas keberhasilan diri. Teori LOC menggolongkan individu termasuk dalam LOC internal atau eksternal. Internal control adalah tingkat dimana seorang individu berharap bahwa hasil dari perilaku mereka bergantung pada perilaku mereka sendiri atau karakteristik personal mereka. Eksternal control adalah tingkat dimana seorang berhadap bahwa hasil adalah fungsi kesempatan, keberuntungan atau takdir dibawah kendali yang lain atau tidak bisa diprediksi.

\section{Komitmen organisasi}

Komitmen organisasi merupakan rasa identifikasi (ketertarikan dan kepercayaan terhadap tujuan dan nilai organisasi), keterlibatan (kesediaan untuk berusaha sebaik mungkin demi kepentingan organisasi) dan loyalitas (keinginan untuk tetap menjadi anggota organisasi yang bersangkutan) yang dinyatakan oleh seorang pegawai terhadap organisasinya.

Komitmen terhadap organisasi artinya lebih dari sekedar keanggotaan formal karena meliputi sikap menyukai organisasi dan kesediaan untuk mengusahakan tingkat upaya yang tinggi bagi kepentingan organisasi demi pencapaian tujuan. Penelitian-penelitian tentang komitmen organisasi telah menghadirkan suatu pandangan yakni munculnya konsensus tentang komitmen organisasi dalam konteks multi dimensional. Penelitian-penelitian tersebut di antaranya menguji pengaruh komitmen organisasi terhadap disfungsional audit, kepuasan kerja karyawan, dan kinerja auditor (Husna et al, 2012:8).

Komitmen organisasi bersifat multidimensi menurut fink mengelompokan ciri-ciri komitmen organisasi adalah sebagai berikut :

1. Selalu berupaya untuk mengsukseskan organisasi

2. Selalu mencari informasi tentang organisasi

3. Selalu mencari keseimbangan antara sasaran organisasi dengan sasaran pribadi

4. Selalu berusaha untuk memaksimumkan kontribusi kerjanya sebagai bagian dari organisasi secara keseluruhan

5. Menaruh perhatian pada hubungan kerja antara unit organisasi

6. Bersifat positif terhadap kriteria dari teman kerja

7. Menempatkan prioritas organisasi di atas dengan departemennya 
8. Tidak melihat organisasi lain sebagai unit yang lebih menarik

9. Memiliki keyakinan bahwa organisasi akan berkembang

10. Berpikir positif pada pimpinan puncak organisasi

\section{Kinerja Auditor}

kinerja adalah kesediaan seseorang atau kelompok orang untuk melakukan suatu kegiatan dan menyempurnakan sesuai dengan tanggung jawabnya dengan hasil yang diharapkan. Menurut Ihyaul Ulum M.D (2012:55) audit kinerja adalah "pengujian sistematis, terorganisasi, dan objektif atas suatu entitas untuk menilai pemanfaatan sumber daya dalam memberikan pelayanan publik secara efisien dan efektif dalam memenuhi harapan stakeholder dan memberikan rekomendasi guna meningkatkan kinerja".

Menurut Mangkunegara (2015:67) pengertian kinerja (prestasi kerja) adalah "hasil kerja secara kualitas dan kuantitas yang dicapai oleh seorang pegawai dalam melaksanakan tugasnya sesuai dengan tanggung jawab yang diberikan kepadanya”.

I Gusti Agung Rai (2011:41) mengemukakan bahwa "audit kinerja merupakan suatu proses sistematis dalam mendapatkan dan mengevaluasi bukti secara objektif atas kinerja suatu organisasi, program, fungsi, atau kegiatan".

Dari beberapa pengertian tersebut, dapat disimpulkan bahwa kinerja auditor adalah suatu hasil yang dicapai oleh seseorang auditor dalam melaksanakan tugas-tugas yang dibebankan kepadanya yang didasarkan atas kecapaian, pengalaman dan kesungguhan waktu yang diukur dengan mempertimbangkan kuantitas, kulitas, dan ketepatan waktu kinerja (presiasi kerja) dapat diukur melalui pengukuran tertentu, dimana kualitas adalah berkaitan dengan mutu kerja yang dihasilkan, sedangkan kuantitas adalah jumlah hasil kerja yang dihasilkan dalam kurun waktu tertentu dan ketepatan waktu adalah kesesuaian waktu yang telah direncanakan.

\section{Jenis Data}

\section{METODE PENELITIAN}

Dalam penelitian ini, peneliti menggunakan data primer untuk mengukur variabel independen (locus of control dan komitmen organisasi), serta variabel dependen (Kinerja Auditor audit) yang diambil dari individu atau perorangan.

\section{Populasi dan Sampel}

Dalam penelitian ini, populasinya adalah semua auditor yang bekerja di Kantor Akuntan Publik wilayah Jakarta Selatan. Sedangkan untuk sampel adalah 100 responden dari 12 Kantor Akuntan Publik. teknik pengambilan sampel yaitu Purposive Sampling yaitu metode pengambilan sampel berdasarkan kriteria tertentu yang ditetapkan peneliti secara objektif.

\section{Metode Analisis Data dan Hipotesis}

Skala pengukuran yang digunakan adalah dengan mengubah skala ordinal ke interval dengan tipe skala Likert 5 (lima) poin dengan rentang angka 1-5 yang memberikan gambaran 
sampai seberapa jauh responden melaksanakan fungsi sesuai dengan pernyataan yang diberikan.

Metode statistika yang digunakan dalam menguji hipotesis dalam penelitian ini adalah dengan Regresi Linear Berganda yang menggunakan program Statistic Program Social Science (SPSS) Versi 21.0. Sebelum menganalisis data akan diuji validitas dan reliabilitas serta uji asumsi klasik.

\section{HASIL DAN PEMBAHASAN}

\section{Pengujian Instrument Penelitian Uji Validitas}

Menurut Ghozali (2013), suatu variabel dikatakan valid apabila nilai $r_{\text {hit }}>r_{\text {tabel }}$. Nilai $r_{\text {tabel }}$ diperoleh melalui rumus df (degree of freedom) $=\mathrm{n}-2$ dimana $\mathrm{n}$ adalah jumlah responden, sehingga $r_{\text {tabel }}$ adalah 0,197 dengan tariff signifikansi $\alpha=5 \%$.tabel berikut menunjukkan hasil uji validitas.

\begin{tabular}{|l|c|c|}
\hline \multicolumn{1}{|c|}{ Variabel Penelitian } & $\begin{array}{c}\text { Corrected Item- } \\
\text { Total Correlation }\end{array}$ & $\begin{array}{c}\text { Total } \\
\text { Pernyataan }\end{array}$ \\
\hline Locus Of Control & $0,331 \mathrm{~s} / \mathrm{d} 0,558$ & 6 \\
\hline Komitmen Organisasi & $0,283 \mathrm{~s} / \mathrm{d} 0,819$ & 10 \\
\hline Kinerja Auditor & $0,332 \mathrm{~s} / \mathrm{d} 0,582$ & 7 \\
\hline
\end{tabular}

Dari hasil Tabel di atas uji validitas tersebut diketahui bahwa $r_{\text {hit }}>r_{\text {tabel }}(0,197)$, sehingga semua variabel yang diuji adalah valid.

\section{Uji Reliabilitas}

Suatu variabel dikatakan reliabel apabila memberikan nilai Cronbach's Alpha $\geq 0,70$. Tabel berikut menunjukkan hasil uji reliabilitas.

\begin{tabular}{|l|c|c|}
\hline \multicolumn{1}{|c|}{ Variabel Penelitian } & Cronbach's Alpha & N of Items \\
\hline Locus Of Control & 0,722 & 6 \\
\hline Komitmen Organisasi & 0,866 & 10 \\
\hline Kinerja Auditor & 0,721 & 7 \\
\hline
\end{tabular}

Dari hasil uji reliabilitas diketahui bahwa Cronbach's Alpha $>0,70$, sehingga semua variabel yang diuji dinyatakan reliabel.

\section{Uji Asumsi Klasik Uji Normalitas}

Dalam penelitian ini, normalitas dapat diketahui dengan melihat tabel One-Sample Kolmogorov-Smirnov Test pada kolom Asymp. Sig. (2-tailed) yaitu data dikatakan berdistribusi normal apabila $\mathrm{p}$ value (Sig.) $>0,05$. Tabel berikut menunjukkan hasil uji normalitas. 
One-Sample Kolmogorov-Smirnov Test

\begin{tabular}{llll} 
& \multicolumn{1}{c}{$X_{1}$} & \multicolumn{1}{c}{$X_{2}$} & $\mathrm{Y}$ \\
\hline $\mathbf{N}$ & 100 & 100 & 100 \\
Kolmogorov-smirnov Z & 0,942 & 0,663 & 0,712 \\
Asymp. Sig. (2-tailed) & 0,337 & 0,772 & 0,691 \\
\hline
\end{tabular}

a. Test distribution is Normal.

b. Calculated from data.

Dari hasil uji normalitas tersebut diketahui bahwa One-Sample Kolmogorov-Smirnov Test pada kolom Asymp. Sig. (2-tailed) atau p value (Sig.) > 0,05, sehingga semua variabel yang diuji dinyatakan berdistribusi normal.

\section{Uji Multikolonieritas}

Untuk mengetahui apakah suatu model regresi bebas dari multikolonieritas, yaitu dapat dilakukan dengan melihat Tolerance $>0,10$ atau sama dengan nilai VIF $<10$. Tabel berikut menunjukkan hasil uji multikolonieritas.

\begin{tabular}{|c|c|c|c|}
\hline \multirow[t]{2}{*}{ Mod } & & \multicolumn{2}{|c|}{ Collinearity Statistics } \\
\hline & & Tolerance & VIF \\
\hline \multirow{3}{*}{1} & (Constant) & & \\
\hline & LOcus Of Control &, 756 & 1,323 \\
\hline & Komitmen Organisasi &, 756 & 1,323 \\
\hline
\end{tabular}

Berdasarkan hasil output SPSS di atas menunjukkan besarnya nilai Tolerance dan Variant Inflation Factor (VIF) untuk masing-masing variabel independen yaitu nilai Tolerance $>0,10$ dan nilai VIF $<10$ sehingga dapat disimpulkan bahwa antar variabel independen tidak terjadi multikolonieritas.

\section{Uji Heteroskedastisitas}

Terdeteksi atau tidaknya heteroskedastisitas dapat dilihat dengan ada tidaknya pola tertentu pada grafik Scatterplot dan uji glejser, nilai sig dibandingkan dengan 0,05. Jika ada pola tertentu maka mengidentifikasikan telah terjadi heteroskedastisitas. Tetapi jika tidak ada pola yang jelas serta titik-titik menyebar di atas dan di bawah angka 0 pada sumbu Y, maka tidak terjadi heteroskedastisitas. Gambar Scatterplot dapat dilihat di bawah ini :

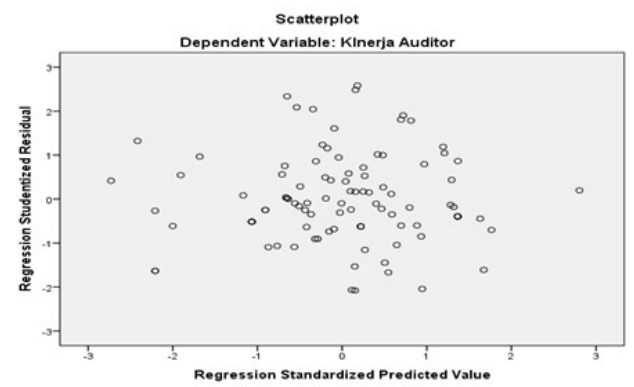


Grafik Scatterplot di atas menunjukkan bahwa data tersebar di atas dan di bawah angka 0 (nol) pada sumbu Y dan tidak terdapat suatu pola yang jelas pada penyebaran data tersebut. Hal ini berarti tidak terjadi heteroskedastisitas pada model persamaan regresi, sehingga model regresi layak digunakan untuk memprediksi Kinerja Auditor berdasarkan Variabel locus of control dan komitmen organisasi. Tabel berikut menunjukkan hasil uji heteroskedastisitas.

Coefficients ${ }^{\mathrm{a}}$

\begin{tabular}{|c|c|c|c|c|c|c|}
\hline \multirow{2}{*}{\multicolumn{2}{|c|}{ Model }} & \multicolumn{2}{|c|}{$\begin{array}{c}\text { Unstandardized } \\
\text { Coefficients }\end{array}$} & \multirow{2}{*}{$\begin{array}{c}\text { Standardized } \\
\text { Coefficients }\end{array}$} & \multirow[t]{2}{*}{$\mathrm{t}$} & \multirow[t]{2}{*}{ Sig. } \\
\hline & & B & Std. Error & & & \\
\hline \multirow{4}{*}{1} & (Constant) & 2,037 &, 973 & & 2,093 & 039 \\
\hline & Locus Of Control &, 068 &, 049 & 159 & 1,389 & , 168 \\
\hline & Komitmen &,- 050 & 028 &,- 208 & $-1,817$ &, 072 \\
\hline & Organisasi & & & & & \\
\hline
\end{tabular}

Dari output di atas dapat dapat diketahui bahwa nilai sig variabel locus of control dan komitmen organisasi diatas 0,05 , Jadi dapat disimpulkan bahwa tidak terjadi heterokedastisitas dalam model regresi atau uji glejser.

\section{Uji Autokorelasi}

Metode pengujian yang sering digunakan adalah dengan uji Durbin-Watson (DW-test) dengan ketentuan sebagai berikut (Ghozali, 2013 : 110-111):

\begin{tabular}{|l|c|c|}
\hline \multicolumn{1}{|c|}{ Hipotesis nol } & Keputusan & Jika \\
\hline Tidak ada autokorelasi positif & Tolak & $0<\mathrm{d}<\mathrm{dl}$ \\
Tidak ada autokorelasi positif & No decision & $\mathrm{dl} \leq \mathrm{d} \leq \mathrm{du}$ \\
Tidak ada korelasi negatif & Tolak & $4-\mathrm{dl}<\mathrm{d}<4$ \\
Tidak ada korelasi negatif & No decision & $4-\mathrm{du} \leq \mathrm{d} \leq 4-\mathrm{dl}$ \\
Tidak ada autokorelasi, positif & Tidak ditolak & $\mathrm{du}<\mathrm{d}<4-\mathrm{du}$ \\
atau negative & & \\
\hline
\end{tabular}

Berdasarkan tabel statistik Durbin-Watson dengan signifikansi 0,05 dan jumlah data (n) = 100 , serta jumlah variabel independen $(\mathrm{k})=2$ diperoleh nilai $\mathrm{dL}$ sebesar 1,6337 dan $\mathrm{dU}$ sebesar 1,7152. Dan untuk mengetahui apakah terdapat autokorelasi dalam model regresi dapat dilihat pada Model Summaryb Tabel sebagai berikut :

Model Summary ${ }^{b}$

\begin{tabular}{l|r|r|r|r|r|}
\hline Model & R & R Square & $\begin{array}{c}\text { Adjusted R } \\
\text { Square }\end{array}$ & $\begin{array}{c}\text { Std. Error of } \\
\text { the Estimate }\end{array}$ & $\begin{array}{c}\text { Durbin- } \\
\text { Watson }\end{array}$ \\
\hline 1 &, $786^{\mathrm{a}}$ &, 618 &, 610 & 2,38541 & 1,858 \\
\hline
\end{tabular}
a. Predictors: (Constant), Komitmen Organisasi, LOcus Of Control
b. Dependent Variable: KInerja Auditor


Dari Tabel Model Summaryb diperoleh nilai yang dihasilkan dari model regresi adalah 1,858 lebih besar dari batas atas (dU) 1,7152 dan kurang 2,2848 (4-dU), maka dapat disimpulkan bahwa tidak bisa menolak Ho yang menyatakan bahwa tidak ada autokorelasi positif atau negatif atau dapat disimpulkan tidak terdapat autokorelasi.

\section{Analisis Regresi Linear Berganda}

Dengan menggunakan Statistical Package for the Social Science (SPSS) versi 21.0. Tabel berikut menunjukkan hasil sebagai berikut :

\section{Coefficients $^{\mathrm{a}}$}

\begin{tabular}{|c|c|c|c|c|c|c|c|c|}
\hline \multirow{2}{*}{\multicolumn{2}{|c|}{ Model }} & \multicolumn{2}{|c|}{$\begin{array}{l}\text { Unstandardized } \\
\text { Coefficients }\end{array}$} & \multirow{2}{*}{\begin{tabular}{|c|}
$\begin{array}{c}\text { Standar } \\
\text { dized } \\
\text { Coeffici } \\
\text { ents }\end{array}$ \\
Beta
\end{tabular}} & \multirow[t]{2}{*}{$\mathrm{T}$} & \multirow[t]{2}{*}{ Sig. } & \multicolumn{2}{|c|}{$\begin{array}{l}\text { Collinearity } \\
\text { Statistics }\end{array}$} \\
\hline & & B & $\begin{array}{l}\text { Std. } \\
\text { Error }\end{array}$ & & & & $\begin{array}{c}\text { Tolera } \\
\text { nce }\end{array}$ & VIF \\
\hline \multirow{3}{*}{1} & (Constant) & 2,268 & 1,566 & & 1,448 &, 151 & & \\
\hline & LOcus Of Control & ,659 &, 079 &, 599 & 8,303 &, 000 &, 756 & 1,323 \\
\hline & Komitmen Organisasi &, 180 &, 044 & ,293 & 4,053 &, 000 &, 756 & 1,323 \\
\hline
\end{tabular}

a. Dependent Variable: KInerja Auditor

Berdasarkan Tabel yang diperoleh dari koefisien regresi di atas, maka dapat dibuat suatu persamaan regresi linear berganda sebagai berikut :

$\mathrm{Y}=2,268+0,659 X_{1}+0,180 X_{2}+e$

Persamaan regresi linear di atas dapat dijelaskan sebagai berikut :

1. Nilai konstanta sebesar 2,268 artinya jika variabel locus of control (X1), Komitmen Organisasi (X2) memiliki nilai sebesar 0 maka variabel Kinerja Auditor (Y) akan memiliki nilai sebesar 2,268.

2. Koefisien regresi variabel locus of control (X1) sebesar 0,659 artinya jika locus of control mengalami kenaikan 1 (satu) satuan, maka akan menaikkan kinerja auditor 0,659 atau $65,9 \%$.

3. Koefisien regresi variabel Komitmen Organisasi (X2) sebesar 0,180 namun jika Komitmen Organisasi mengalami kenaikan 1 (satu) satuan, maka akan menaikkan kinerja auditor 0,180 atau $18 \%$.

\section{Uji Hipotesis \\ Uji t (uji parsial)}

Pengujian ini dinilai dengan taraf signifikansi $\alpha=5 \%$. Selanjutnya untuk mengetahui signikansi pengaruh atau hubungan antara variabel dilakukan dengan kriteria pengujian sebagai berikut :

1. Jika Sig. $<0,05$, maka Ho ditolak dan Ha diterima

2. Jika Sig. $>0,05$, maka Ho diterima dan Ha ditolak

Menentukan nilai $t_{\text {tabel }}$ dapat ditentukan dengan tingkat signifikansi 5\% $=0.05$ dengan derajat kebebasan $\mathrm{df}=\mathrm{n}-\mathrm{k}-1$ atau $\mathrm{df}=97$. Hasil yang diperoleh untuk ttabel sebesar 1,985. Kriteria pengujian yang digunakan adalah :

Jika $t_{\text {hitung }}>$ ttabel (n-k-1) maka Ho ditolak

Jika $t_{\text {hitung }}<$ ttabel (n-k-1) maka Ho diterima 
Berdasarkan Tabel yang telah diperoleh dari koefisien regresi di atas, maka dapat hasil uji parsial (uji t) sebagai berikut :

\section{locus of control (X1) berpengaruh positif dan signifikan terhadap Kinerja Auditor (Y)}

Hasil pengujian statistik menunjukkan bahwa locus of control memiliki nilai $t_{\text {hitung }}$ sebesar 8,303 dimana $t_{\text {hit }} \quad$ bernilai lebih besar dari $t_{\text {tabel }}$ sebesar 1,985 $(8,303>1,985)$ dan tingkat signifikan sebesar 0,000. Hal ini menyatakan bahwa Ho ditolak dan Ha diterima, artinya bahwa locus of control berpengaruh secara positif dan signifikan terhadap Kinerja auditor sebesar $65,9 \%$.

Dapat disimpulkan bahwa Locus of Control merupakan keadaan dimana pandangan hidup auditor menurut internal dan external LOC sangat berbeda. Pada individu yang mempunyai external Locus of Control akan memandang dunia sebagai sesuatu yang tidak dapat diramalkan, demikian juga dalam mencapai tujuan sehingga perilaku individu tidak akan mempunyai peran di dalamnya Locus of control eksternal diidentifikasikan lebih banyak menyandarkan harapannya untuk bergantung pada orang lain, hidup mereka cenderung dikendalikan oleh kekuatan di luar diri mereka sendiri (seperti keberuntungan), serta lebih banyak mencari dan memilih kondisi yang menguntungkan.

Berdasarkan penjelasan di atas, auditor dapat melakukan disfungsional audit ketika menghadapi ketidak percayaan pada diri sendiri atau dengan lingkungannya dalam menyelesaikan sebuah tugas audit. Semakin tinggi tingkat Locus of Control eksternal pada diri auditor, maka semakin tinggi kesempatan auditor melakukan disfungsional audit. Maka, dapat disimpulkan bahwa Locus of Control eksternal mempunyai pengaruh yang signifikan terhadap disfungsional audit. Hasil penelitian ini menunjukkan hasil yang berbeda dengan penelitian sebelumnya, yaitu penelitian yang dilakukan oleh Mindarti (2015), menemukan bahwa Locus of Control pengaruh negatif terhadap kinerja auditor.

\section{komitmen organisasi (X2) berpengaruh positif dan signifikan terhadap Kinerja Auditor} (Y).

Hasil pengujian statistik menunjukkan bahwa komitmen organisasi memiliki nilai $t_{\text {hitu }}$ sebesar 4,053 dimana $t_{\text {hitung }}$ bernilai lebih besar dari $t_{\text {tabel }}$ sebesar 1,985 (4,053 > 1,985) dan tingkat signifikan sebesar 0,000. Hal ini menyatakan bahwa Ho ditolak dan Ha diterima, artinya bahwa komitmen organisasiberpengaruh secara positif dan signifikan terhadap Kinerja auditor sebesar $18 \%$.

Dapat disimpulkan, Hasil penelitian inimemberikan bukti empiris bahwa seorang auditor yang memiliki komitmen organisasi yang tinggi maka auditor tersebut tidak menunjukkan kecenderungan untuk menerima perilaku penyimpangan audit sebagaimana yang dihipotesiskan. Secara teoritis komitmen organisasi terdiri dari 3 bentuk komitmen yaitu komitmen afektif, normative dan kontinu. Berkaitan dengan perilaku negative fungsi seperti perilakupenerimaan disfungsional audit dalam hal ini nampaknya terdapat kondisi yang tidak searah antar komitmen kontinyu dan komitmen afektif dan normative. Dalam komitmen kontinyu terkandung makna bahwa keinginan auditor untuk bekerja didalam perusahaan audit (KAP) dapat mendorong mereka untuk menerima perilaku disfungsional, namun di sisi lain komitmen afektif yang merupakan cerminan perasaan dari auditor untuk menjunjung tinggi nama KAP justru dapat menolak untuk menerima perilaku disfungsional dengan pertimbangan bahwa KAP sebagai organisasi harus profesional. Dengan kata lain komitmen 
organisasi (afektif) yang tinggi akan menciptakan keinginan untuk meningkatkan kinerja KAP, sedangkan kualitas KAP dapat ditunjukkan dengan pelaksanaan prosedur yang benar yang dilakukan oleh auditornya.

Hasil penelitian ini mengindikasikan auditor yang tidak memiliki komitmen organisasi yang kuat cenderung melakukan perilaku disfungsional dalam pelaksanaan program audit. Komitmen pada organisasi merupakan alat prediksi yang sangat baik untuk beberapa perilaku penting, diantaranya adalah perputaran pegawai, kesetiaan pegawai kepada nilai organisasi dan keinginan mereka untuk melakukan pekerjaan ekstra (untuk melakukan pekerjaan melebihi apa yang seharusnya dikerjakan).

Karena risiko melakukan perilaku disfungsional tinggi, maka auditor yang dengan tidak memiliki komitmen organisasi yang kuat cenderung melakukan perilaku disfungsional dalam pelaksanaan program audit. Berdasarkan penjelasan di atas, semakin rendah komitmen organisasi akan berdampak pada terjadinya praktek disfungsional audit. Hasil penelitian ini menunjukkan hasil yang sama dengan penelitian sebelumnya, yaitu penelitian yang dilakukan oleh Wibowo (2009), menemukan bahwa komitmen organisasional berpengaruh positif dan signifikan terhadap kinerja auditor.

\section{Uji Simultan (Uji F)}

Jika probabilitas $<0,05$, maka dapat dikatakan terdapat pengaruh yang signifikan antar variabel bebas secara bersama-sama terhadap variabel terikat dan model regresi bisa dipakai untuk memprediksi variabel terikat. Atau jika nilai signifikansi $>0,05$ maka tidak terdapat pengaruh yang signifikan secara bersama-sama antara variabel bebas terhadap variabel terikat.

a. Jika Sig. $<0,05$, maka Ho ditolak dan Ha diterima

b. Jika Sig. $>0,05$, maka Ho diterima dan Ha ditolak

Hasil uji F dapat dilihat pada Tabel di bawah ini :

ANOVA $^{\mathrm{a}}$

\begin{tabular}{|c|c|c|c|c|c|c|}
\hline \multicolumn{2}{|c|}{ Model } & $\begin{array}{l}\text { Sum of } \\
\text { Squares }\end{array}$ & $\mathrm{df}$ & $\begin{array}{c}\text { Mean } \\
\text { Square }\end{array}$ & F & Sig. \\
\hline \multirow{3}{*}{1} & Regression & 893,011 & 2 & 446,506 & 78,470 &, $000^{\mathrm{b}}$ \\
\hline & Residual & 551,945 & 97 & 5,690 & & \\
\hline & Total & 1444,957 & 99 & & & \\
\hline
\end{tabular}

a. Dependent Variable: KInerja Auditor

b. Predictors: (Constant), Komitmen Organisasi, LOcus Of Control

\section{locus of control (X1) dan komitmen organisasi (X2) berpengaruh positif dan signifikan terhadap Kinerja Auditor (Y)}

Hasil pengujian statistik menunjukkan $f_{\text {hitun }}$ sebesar 78,470 dimana $f_{\text {hitun }}$ bernilai lebih besar dari $f_{\text {tabel }}$ sebesar 3,09 (78,470>3,09 dan tingkat signifikan sebesar 0,000 yang memiliki nilai lebih kecil dari 0,05 $(0,000<0,05)$. Maka dapat disimpulkan bahwa locus of control, komitmen organisasi secara simultan berpengaruh signifikan terhadap kinerja auditor. Diperoleh nilai koefisien determinasi (Adjusted R2) sebesar 0,610 Ini menunjukkan bahwa sebesar $61 \%$ variabel locus of control, komitmen organisasi memiliki pengaruh yang cukup signifikan terhadap kinerja auditor. Berarti bahwa kinerja auditor yang dihasilkan 
auditor tidak terlepas dari locus of control, komitmen organisasi yang baik untuk dapat melaksanakan dan menyelesaikan pekerjaan auditnya dengan baik. Sedangkan sebagian sebesar 39\% dipengaruhi oleh variabel lain yang tidak diteliti dalam penelitian ini, seperti motivasi kerja, gaya kepemimpinan, pengalaman kerja dll.

\section{Kesimpulan}

\section{KESIMPULAN DAN SARAN}

Berdasarkan hasil penelitian ini mengenai tentang locus of control, komitmen organisasi terhadap kinerja auditor yang dikumpulkan pada beberapa KAP di wilayah Jakarta Selatan, maka dapat ditarik kesimpulan sebagai berikut :

1. locus of control berpengaruh positif dan signifikan terhadap kinerja auditor sebesar $65,9 \%$. Berarti bahwa semakin meningkatnya locus of control yang dimiliki oleh seorang auditor, maka semakin baik pula kinerja auditor yang dihasilkan oleh auditor tersebut.

2. komitmen organisasi berpengaruh positif dan signifikan terhadap kinerja auditor sebesar $18 \%$. Berarti bahwa adanya komitmen, rasa pengabdian pada lingkungan kerja seorang auditor dapat meningkatkan kinerja auditor yang baik.

3. Hasil penelitian ini menunjukkan bahwa locus of control, komitmen organisasi secara bersama-sama memiliki pengaruh positif dan signifikan terhadap kinerja auditor sebesar $61 \%$. Berarti bahwa adanyalocus of control, komitmen organisasi secara bersama-sama dapat mempengaruhi kinerja auditor yang cukup signifikan, sedangkan sebagian sebesar 39\% dipengaruhi oleh faktor-faktor lain di luar penelitian ini, motivasi kerja, gaya kepemimpinan, pengalaman kerja dll.

\section{Saran}

Harapan peneliti pada penelitian selanjutnya yaitu dapat memperbaiki kekurangankekurangan dalam penelitian ini, diantaranya :

1. Sebaiknya penyebaran kuesioner tidak dilakukan pada waktu yang bertepatan dengan kesibukan para auditor atau pada waktu yang lebih banyak agar efisien sampai pengembalian kuesioner. Sehingga kuesioner yang disebarkan mendapat tanggapan yang baik.

2. Melakukan penelitian dalam lingkup yang lebih luas sehingga dapat memperoleh data dan hasil analisa yang lebih akurat.

3. Melanjutkan dan mengulang kembali penelitian tentang pengaruh locus of control, dan kommitmen organisasi agar dapat diperoleh bukti empiris tambahan, apakah kelima variabel tersebut memiliki korelasi.

4. Mengembangkan penelitian dengan menambahkan faktor-faktor dan variabel lain di luar model penelitian ini seperti seperti seperti motivasi kerja, gaya kepemimpinan, pengalaman kerja dll. Hal ini untuk menambah daftar literatur penelitian, serta mengembangkan ilmu pengetahuan secara akademik yang dapat digunakan sebagai referensi bagi peneliti selanjutnya. 


\section{DAFTAR PUSTAKA}

Agoes, Sukrisno. 2016. Auditing : Petunjuk Praktis Pemeriksaan Akuntan oleh Kantor Akuntan Publik. Jakarta: Salemba Empat.

Elder, Randal J, et al. 2011. Jasa Audit Dan Assurance. Jakarta: Salemba Empat.

Ghozali, Imam. 2013. Aplikasi Analisis Multivariete Dengan Program IBM SPSS 21 edisi VII. Semarang: Universitas Diponogoro.

Halim, Abdul. 2008. Auditing I (Dasar-dasar, Edisi Ketiga Audit Laporan Keuangan). Yogyakarta: UPP AMP YKPN.

Harini, Dwi., Agus Wahyudin dan Indah Anisykurlillah. 2010. “Analisis penerimaan auditor atas Dysfunctional audit behavior: Sebuah pendekatan karakteristik personal auditor”. Simposium Nasional Akuntansi XIII Purwokerto.

Kulsum, M.PD, Umi \& Muhammad Jauhar, S.PD. 2014. Pengaruh Psikologi Sosial, Jakarta: Tim Prestasi Pustaka.

Lina Febrina, Husna. Basuki Hadiprayitno. 2012. "Analisis Pengaruh Karakteristik Personal Auditor Terhadap Penerimaan Auditor Atas Dysfunctional Audit Behavior (Studi Empiris pada Kantor Akuntan Publik di Jawa Tengah dan Yogyakarta)". Universitas Diponegoro, Semarang.

Mangkunegara, Dr. A. A. Anwar Prabu, 2015. Manajemen Sumber Daya Manusia Perusahaan. Bandung: Rosda

Mulyadi. 2014. Auditing. Buku Satu, Edisi Keenam. Jakarta: Salemba Empat.

Rai, I Gusti Agung. 2011. Audit Kinerja Pada Sektor Publik. Jakarta: Salemba Empat.

Sugiyono, 2016. Metode Penelitian Kuantitatif, Kualitatif, dan $R \& D$ Cetakan ke-23. Bandung: Alfabeta.

Thoha, Miftah. 2017. Perilaku Organisasi Konsep Dasar Dan Aplikasinya. Jakarta: Rajawali Pers.

Ulum M.D, Ihyaul. 2012. Audit Sektor Publik. Jakarta: Bumi Aksara.

\section{Jurnal penelitian terdahulu :}

Ceacilia Sri Mindarti (2015). Pengaruh Karakteristik Individu Terhadap Kinerja Auditor Hal. 59-60

Desak Made Putri Sanjiwani Dan I Gede Suparta Wisadga (2016). Pengaruh Locus Of Control, Gaya Kepemimpinan, Dan Komitmen Organisasi Terhadap Kinerja Auditor Kantor Akuntan Publik

Ni Meda Mas Sendhi Rahayu Dan I Dewa Nyoman Badera (2017). Pengeruh Locus Of Contol Internal, Motivasi Kerja, Gaya Kepemimpinan Transformasional, Komitmen Organisasi Pada Kinerja Auditor 